\title{
Nutrient intake and quantitative aspects of carcass of finishing sheep fed with diets containing cashew nut meal
}

\author{
Consumo de nutrientes e aspectos quantitativos de carcaça de ovinos em terminação \\ alimentados com dietas contendo farelo de castanha de caju
}

\author{
NASCIMENTO, Emiliano Nunes do ${ }^{1}$; ROGÉRIO, Marcos Cláudio Pinheiro ${ }^{2}$; BATISTA, \\ Ana Sancha Malveira ${ }^{1}$; CARNEIRO, Maria Socorro de Souza ${ }^{3}$; VASCONCELOS, Angela \\ Maria de ${ }^{1}$; LEITE, Eneas Reis ${ }^{1}$; LANDIM, Aline Vieira ${ }^{1}$; SILVA, Vandenberg Lira ${ }^{5}$; \\ COSTA, Joaquim Bezerra ${ }^{4}$; COSTA, Hélio Henrique Araújo ${ }^{*}$
}

\footnotetext{
${ }^{1}$ Universidade Vale do Acaraú, Centro de Ciências Agrárias e Biológicas, Departamento de Zootecnia, Sobral, Ceará, Brasil.

${ }^{2}$ Embrapa Caprinos e Ovinos, Sobral, Ceará, Brasil.

${ }^{3}$ Universidade Federal do Ceará, Centro de Ciências Agrárias, Departamento de Zootecnia, Fortaleza, Ceará, Brasil. ${ }^{4}$ Embrapa Cocais, São Luís, Maranhão, Brasil.

${ }^{5}$ Univesidade Federal de Minas Gerais, Escola de Veterinária, Departamento de Zootecnia, Belo Horizonte, Minas Gerais, Brasil.

*Endereço para correspondência: helioa.costa@gmail.com
}

\section{SUMMARY}

This work aimed to determine the nutrient intake and quantitative aspects of sheep carcass from three different genetic groups. Eighteen animals with initial average body weight of $20.1 \mathrm{~kg}$ were used in a completely randomized design, in a factorial 3x2 scheme (three different crossbreeds 6 F1Dorper $\mathrm{x}$ non defined breed, 6 F1Somalis $\mathrm{x}$ non defined breed and 6 F1Santa Inês $x$ non defined breed versus two diets). The diets fed to the animals were formulated with or without cashew nuts. The inclusion of cashew nut meal in the diet influenced nutrient intake. Differences of intake among the animal groups were observed as higher intake for F1Dorper $\mathrm{x}$ non defined breed (NDB), followed by F1Somalis $x$ NDB and for F1Santa Inês x NDB. However, the control diet produced no difference among these genotypes. The average daily gain was lower for both crossbreeds when cashew nut meal was added in the diets. The evaluated crossbreeds and diets did not affect the feed:gain ratio. The carcasses analyses showed that the inclusion of cashew nut meal in the diets reduced the cold carcass weight and the rib weight. The addition of cashew nut meal in the diets for lambs reduces food intake and carcass yield. The crossbreed F1Dorper $\mathrm{x}$ NDB presented the higher rate of average daily gain.

Keywords: sheep crossbreeds, cashew byproducts, ruminant nutrition, sheep performance.

\section{RESUMO}

Objetivou-se determinar o consumo de nutrientes e os aspectos quantitativos da carcaça de ovinos de diferentes grupos genéticos com dietas com ou sem farelo de castanha de caju. Foram usados dezoito ovinos com peso inicial médio de $20,1 \mathrm{~kg}$ em um delineamento inteiramente casualizado, em esquema fatorial $3 \times 2$ (três cruzamentos e duas dietas diferentes). A inclusão do farelo de castanha de caju influenciou $(\mathrm{P}<0,05)$ o consumo de nutrientes. Diferenças de consumo entre as raças resultaram em maior consumo para os animais mestiços Dorper $\mathrm{x}$ sem padrão racial definido (SPRD), seguidos pelos mestiços 
Somalis x SPDR e pelos mestiços Santa Inês x SPRD. No entanto, não houve diferenças entre os genótipos em relação à dieta controle. $\mathrm{O}$ ganho de peso médio diário foi menor para as raças a cuja dieta foi adicionado farelo de castanha de caju. Os diferentes cruzamentos e as dietas não afetaram a conversão alimentar. A inclusão de farelo de castanha de caju nas dietas reduziu o peso de carcaça fria, bem como o peso das costelas. A adição de farelo de castanha de caju diminui o consumo de alimentos e o rendimento de carcaça. Entre os cruzamentos avaliados neste estudo, os ovinos mestiços Dorper x SPRD apresentam maior taxa de ganho de peso médio diário.

Palavras-chave: raças ovinas, desempenho animal, nutrição de ruminantes, subprodutos do caju.

\section{INTRODUCTION}

The Northeast Region had $56.7 \%$ of the currently Brazilian sheep flock (17.4 million heads) - (IBGE, 2011). According to Simplício and Simplício (2006), the stability of the sheep meat market depends on maintaining a steady supply of a uniform product that meets the requirements of each market and presents competitive prices. Therefore, adequate nutrition of livestock is fundamental to improve the animal performance and the quality of their products (MENEZES et al., 2005).

The commercial flocks of meat sheep from Brazilian Northeast Region are generally resulted from crossings between males from specific breeds for meat production with ewes from native breeds (AMARAL et al., 2011a). Aspects related to the potential for body weight gain and feed:gain ratio are interrelated and should receive special attention, since these aspects can provide improved animal performance and higher profit in sheep production systems in the semi-arid Northeast of Brazil.

The cashew nut meal is an important agro-industrial by-product available during the dry season of Brazilian Northeast Region, when food shortages are common and when the available forage has low nutritional value (SILVA et al., 2011). In addition, the cashew nut meal may contribute to improve dietary energy, given the high levels of ether extract $(42.49 \%$ in dry matter basis) and high percentage of crude protein $(24.54 \%$ $\mathrm{CP}$ in dry matter) (PIMENTEL et al., 2007; SILVA, 2010). Therefore, this may constitute an important alternative and affordable feed for small ruminant diets, replacing the traditional concentrates.

The objective of this study was to determine the nutrient intake and quantitative aspects of carcass in finishing lambs fed with cashew nut meal.

\section{MATERIAL AND METHODS}

The experiment was carried out at the Division for Animal Digestibility on the Experimental Farm of Vale do Acaraú, within the State University of Vale do Acaraú (UVA) in Sobral, Ceará state, Brazil. Humane animal care and handling procedures were followed according to the University's animal care committee.

Diets were formulated to be isonitrogenous and isoenergetic according to the nutritional requirements recommended by NRC (1985) for finishing lambs with an average daily gain of 250 grams per day. The control diet consisted of Aruana grass (Panicum maximum cv. Aruana) hay, soybean meal and ground corn. The cashew nut meal (CNM) was added to these ingredients for another experimental 
diet. The highest level of inclusion of cashew nut meal in the diets was determined by the content of dietary ether extract at a maximum of $7 \%$ of dry matter, according to Palmquist \& Jenkins (1980). When including CNM in the diet, the by-product represented $13.31 \%$ of total diet or $22.43 \%$ of the concentrate feed.

Eighteen three months old sheep with average body weight of $20.07+4.12 \mathrm{~kg}$ were used for the evaluations. A completely randomized design was used with a $3 \times 2$ factorial scheme, including three genetic groups (6 F1Dorper $\mathrm{x}$ non defined breed, 6 F1Somalis x non defined breed and 6 F1Santa Inês $x$ non defined breed) and two experimental diets (with or without inclusion of $\mathrm{CNM}$ ), resulting in six experimental treatments with three animals (replications) in each treatment. The animals were previously dewormed and then housed individually in metabolic cages equipped with feeders, drinkers and plastic salt shakers, where they remained throughout the experimental period. The diets were divided into two equal meals and offered at 8 am and $5 \mathrm{pm}$, allowing an average leftover (in dry matter basis) between 10 and $20 \%$ per day. Water and mineralized salt were available ad libitum.

The weekly samples of feed offered and leftovers were collected, weighed and stored in labeled plastic bags, at an average temperature of $-5^{\circ} \mathrm{C}$. The intake and feed:gain ratio were calculated using the daily weigh of leftovers. At the end of the experimental period, all samples were dried in a kiln of forced air at a temperature of $65^{\circ} \mathrm{C}$ for 72 hours. Later they were crushed in Thomas Myller mill with a $0.5 \mathrm{~mm}$ sieve and then stored for later laboratory analyses.
Dry matter (DM), organic matter (OM), ash, ether extract (EE) and crude protein (CP) of the feed supplied and leftovers were determined following the methodology proposed by AOAC (2006). For the quantification of neutral detergent fiber (NDF), acid detergent fiber (ADF), cellulose, hemicellulose and lignin in the feeds was used the methodology proposed by Van Soest et al. (1991). Alpha-amylase was used for the concentrates feedstuffs.

The totals digestible nutrients (TDN) of the feedstuffs were calculated according to Cappelle et al. (2001). To diets, the TDN were calculated according Sniffen et al. (1992).

The chemical composition of the feedstuff can be observed in Table 1 .

The feedlot comprised a period of the 64 days. The 10 initial days for adaptation of the animals to cages and diets, and the next 54 days after adaptation period were used for the trial period. The animals were weighed at the beginning of the adaptation period to adjust the amount of leftovers and to calculate the intake as per unit of metabolic body weight $\left(\mathrm{g} / \mathrm{BW}^{0.75}\right)$. The body weight gain was checked until the lambs reached $30 \mathrm{~kg}$ of body weight and/or 153 days old.

In the day of slaughter the animals were weighed after fasting for 16 hours to empty their intestinal tract to facilitate the removal of viscera without contamination of carcass. The slaughter was by cerebral concussion, followed by bleeding and skinning. The head was removed and by through longitudinal cutting of the carcass two symmetrical halves were obtained. The slaughter weight (SW), the hot carcass weight $(\mathrm{HCW})$, cold carcass weight $(\mathrm{CCW})$ and the cold carcass yield $(\mathrm{CCY}=\mathrm{CCW} / \mathrm{SW} \times 100)$ were evaluated. 
Table 1. Chemical composition (in \%) of feedstuffs, in dry matter, supplied to experimental sheep

\begin{tabular}{lcccc}
\hline \multirow{2}{*}{ Nutrients } & \multicolumn{3}{c}{ Feedstuffs } \\
\cline { 2 - 5 } & AGH & CNM & Ground Corn & Soybean Meal \\
\hline Dry matter in basis of natural matter & 91.25 & 95.5 & 90.7 & 89.6 \\
Crude protein & 7.34 & 24.5 & 10.63 & 45.9 \\
NDIN (\% of total nitrogen) & 57.9 & 54.7 & 93.5 & 31.0 \\
ADIN (\% of total nitrogen) & 40.9 & 19.9 & 3.53 & 21.3 \\
Ether extract & 1.45 & 42.5 & 6.59 & 1.34 \\
Neutral detergente fiber (NDF) & 78.6 & 21.0 & 18.3 & 19.4 \\
NDF truly digestible & 37.6 & 0.200 & 3.73 & 1.11 \\
Acid detergente fiber & 45.0 & 11.3 & 4.42 & 12.1 \\
Hemicellulose & 33.6 & 18.6 & 17.5 & 17.0 \\
Cellulose & 36.7 & 7.84 & 4.03 & 9.80 \\
Lignin & 4.32 & 3.63 & 0.68 & 1.56 \\
Ash & 9.04 & 7.07 & 2.03 & 6.16 \\
Calcium & 1.20 & 0.100 & 0.900 & 0.270 \\
Phosphorus & 0.420 & 0.510 & 0.260 & 0.590 \\
Total carbohydrates & 82.2 & 25.9 & 80.7 & 46.5 \\
Non-fiber carbohydrates & 10.5 & 9.77 & 62.9 & 39.9 \\
Total digestible nutrients* & 46.1 & 80.6 & 72.3 & 71.9 \\
\hline
\end{tabular}

$\mathrm{AGH}=$ aruana- grass hay; $\mathrm{CNM}=$ cashew nut meal, NDIN = neutral detergent insoluble nitrogen; $\mathrm{ADIN}=$ acid detergent insoluble nitrogen.

*According to Cappelle et al. (2001).

The carcasses were packed in high density polyethylene bags and stored in cold room for 24 hours at a temperature varying from $2^{\circ} \mathrm{C}$ to $4^{\circ} \mathrm{C}$. Then, the carcasses were split longitudinally and the half carcass left was sectioned into five anatomical regions (commercial cuts): neck, shoulder, ribs, loin and leg. Each cut was weighed separately. The percentage of each cut obtained was calculated in relation to the left half carcass according by Moreno et al. (2010). The centesimal and chemical composition of diets can be checked in Table 2.
A completely randomized design was used with a $3 \times 2$ factorial scheme (three crossbreeds and two experimental diets). Statistical analyses were done by the software SAEG 8.0 (UFV, 2000). The averages obtained were statistically compared by SNK test and the significance was declared in $5 \%$ $(\mathrm{P}<0.05)$. The Pearson correlations were also analyzed according to Sampaio (2007). The initial body weight measured at the beginning of the experiment was used as covariate. 
Table 2. Percentage of each feed and chemical composition of diets provided to sheep

\begin{tabular}{|c|c|c|c|c|}
\hline \multicolumn{5}{|c|}{ Centesimal composition (\%) } \\
\hline Experimental diets & $\begin{array}{c}\text { Aruana-grass } \\
\text { hay }\end{array}$ & $\begin{array}{c}\text { Caschew nut } \\
\text { meal }\end{array}$ & $\begin{array}{l}\text { Ground } \\
\text { Corn }\end{array}$ & $\begin{array}{c}\text { Soybean } \\
\text { meal }\end{array}$ \\
\hline With cashew nut meal & 40.6 & 13.31 & 31.83 & 14.20 \\
\hline $\begin{array}{l}\text { Without cashew nut } \\
\text { meal }\end{array}$ & 41.5 & - & 39.58 & 18.95 \\
\hline \multicolumn{5}{|c|}{ Chemical composition the diets experimental } \\
\hline Nutrients & & Diet with CNM & Diet & Nithout CNM \\
\hline Dry matter in basis of $n$ & al matter & 91.4 & & 90.7 \\
\hline Crude protein & & 16.2 & & 16.0 \\
\hline NDIN (of total nitrogen & & 65.0 & & 66.9 \\
\hline ADIN (of total nitrogen & & 20.6 & & 22.4 \\
\hline Ether extract & & 8.53 & & 3.46 \\
\hline Neutral detergente fiber & DF) & 43.3 & & 43.5 \\
\hline NDF truly digestible & & 16.7 & & 17.3 \\
\hline Acid detergente fiber & & 22.9 & & 22.7 \\
\hline Hemicellulose & & 24.1 & & 24.1 \\
\hline Cellulose & & 18.6 & & 18.7 \\
\hline Lignin & & 2.68 & & 2.36 \\
\hline Ash & & 9.04 & & 9.04 \\
\hline Calcium & & 0.830 & & 0.910 \\
\hline Phosphorus & & 0.490 & & 0.310 \\
\hline Total carbohydrates & & 69.2 & & 74.9 \\
\hline Non-fiber carbohydrate & & 30.8 & & 36.2 \\
\hline Total digestible nutrient & & 78.8 & & 75.6 \\
\hline
\end{tabular}

NDIN = neutral detergent insoluble nitrogen; ADIN = acid detergent insoluble nitrogen .

*According to Sniffen et al. (1992).

\section{RESULTS AND DISCUSSION}

The inclusion of CNM in the diets promoted reduction in the use of traditional concentrates (ground corn and soybean meal) (Table 1) without reduces for diets levels of $\mathrm{CP}$, TDN and NDF presents in the diet (Table 2). This is due to the CNM chemical characteristics (Table 1), which has high levels of lipids and proteins, thus represents advantages for feedlot systems of meat sheep in the
Brazilian Northeast because commercial concentrates have higher price fluctuations during the year.

The inclusion of the CNM as lipid source to obtain higher energy content in animals rations reduces the risk of rumen acidosis and leads to better productive and reproductive performance of the animals (PIMENTEL et al. 2007).

The TDN (Table 2) in the diets were according to recommendations of the NRC (2007), i.e. 66.02\%, considering late maturity lambs with 4 months old and an 
average daily gain of $200 \mathrm{~g}$. The $\mathrm{CP}$ in the diets had averages of $16.2 \%$ (with CNM) and $16.0 \%$ (and without CNM) were higher than those prescribed by the NRC (2007), $11.4 \%$ and $12.5 \%$. With regard to $\mathrm{CP}$, if the dietary formulations had followed the NRC (2007), not existing at the time when this research was carried out, CP values would probably not be exceeded and the inclusion of protein concentrate could be even lower, and it would be a possible advantage for cheapening costs.

Differences in percentage of each feed and diets chemical compositions between the calculated and the actually consumed values of diets may occur due to the animal selectivity. However, the maximum limit of lipids should be respected in diet for ruminants, and high levels of EE (above 7\% in dry matter) can affect the action of microorganisms on the dietary fiber degradation (DEVENDRA \& LEWIS, 1974).

A significant interaction $(\mathrm{P}<0.05)$ between crossbreeds and experimental diets was observed for nutrients intake in grams per unit of metabolic body weight $\left(\mathrm{g} / \mathrm{BW}^{0.75}\right)$ - (Table 3$)$. The inclusion of $\mathrm{CNM}$ in the diets promoted differences for intake among genetic groups. The intake of $\mathrm{DM}, \mathrm{OM}, \mathrm{CP}$ and NDF $\left(\mathrm{g} / \mathrm{BW}^{0.75}\right)$ in the diets with $\mathrm{CNM}$ was higher for F1Dorper x NDB, followed by F1Somalis $x$ NDB and the lowest intake was found in F1Santa Inês x NDB.

Among the crossbreeds, the diet with $\mathrm{CNM}$ reduced the intake for $\mathrm{F} 1$ Somalis $\mathrm{x}$ NDB and F1Santa Inês x NDB, though not interfered in the F1Dorper $x$ NDB intake (Table 3). High correlation was observed between DM and OM intakes ( $\mathrm{r}$ $=0.9999 ; \mathrm{P}<0.00001)$.

Table 3. Nutrients intake $\left(\mathrm{g} / \mathrm{BW}^{0.75}\right)$ of lambs from different crossbreeds being provided with diets with or without cashews nut meal (CNM)

\begin{tabular}{|c|c|c|c|c|c|}
\hline \multirow[b]{2}{*}{ Intake $\left(\mathrm{g} / \mathrm{BW}^{0,75}\right)$} & \multirow[b]{2}{*}{ Diets } & \multicolumn{4}{|c|}{ Crossbreeds } \\
\hline & & $\begin{array}{c}\text { F1Dorper } \\
\text { x NDB }\end{array}$ & $\begin{array}{l}\text { F1Somalis } \mathrm{x} \\
\text { NDB }\end{array}$ & $\begin{array}{c}\text { F1Santa Inês x } \\
\text { NDB }\end{array}$ & $\begin{array}{l}\mathrm{CV} \\
(\%)\end{array}$ \\
\hline \multirow{2}{*}{ Dry Matter } & Without CNM & $74.0^{\mathrm{Aa}}$ & $81.5^{\mathrm{Aa}}$ & $79.4^{\mathrm{Aa}}$ & \multirow{2}{*}{6.58} \\
\hline & With CNM & $80.3^{\mathrm{Aa}}$ & $71.3^{\mathrm{Bb}}$ & $59.3^{\mathrm{Bc}}$ & \\
\hline \multirow{2}{*}{ Organic Matter } & Without CNM & $64.0^{\mathrm{Aa}}$ & $70.4^{\mathrm{Aa}}$ & $68.5^{\mathrm{Aa}}$ & \multirow{2}{*}{6.61} \\
\hline & With CNM & $69.6^{\mathrm{Aa}}$ & $61.9^{\mathrm{Bb}}$ & $51.5^{\mathrm{Bb}}$ & \\
\hline \multirow{2}{*}{ Crude Protein } & Without CNM & $12.6^{\mathrm{Aa}}$ & $13.6^{\mathrm{Aa}}$ & $13.3^{\mathrm{Aa}}$ & \multirow{2}{*}{6.78} \\
\hline & With CNM & $13.6^{\mathrm{Aa}}$ & $12.0^{\mathrm{Bb}}$ & $9.9^{\mathrm{Bc}}$ & \\
\hline Neutral & Without CNM & $22.8^{\mathrm{Aa}}$ & $25.3^{\mathrm{Aa}}$ & $24.9^{\mathrm{Aa}}$ & \multirow{2}{*}{6.25} \\
\hline Detergent Fiber & With CNM & $24.9^{\mathrm{Aa}}$ & $22.2^{\mathrm{Bb}}$ & $18.9^{\mathrm{Bc}}$ & \\
\hline
\end{tabular}


The DM intake average daily was $74.3 \mathrm{~g} / \mathrm{BW}^{0.75}$. According to the NRC (2007), considering the nutritional requirements for lambs evaluated in this study, the requirement is $85.03 \mathrm{~g}$ of $\mathrm{DM} / \mathrm{BW}^{0.75}$ per day, higher than value observed here (Table 3). However, F1Dorper $x$ NDB when received diet containing CNM and F1Somalis $\mathrm{x}$ NDB when received diet without $\mathrm{CNM}$ showed DM intake averages values of 80.25 and $81.53 \mathrm{~g} / \mathrm{BW}^{0.75}$, respectively. Those values were closer to the NRC (2007) recommendation.

When the absorption of nutrients (especially protein and energy) exceeds requirements, or when the proportion of nutrients absorbed is inadequate, there is an inhibition of DM intake. In this case, the intake physiological regulation is due to the nutritional status or the energy balance (MERTENS 1997). This may have influenced the lower DM and OM Intakes $\left(\mathrm{g} / \mathrm{BW}^{0.75}\right)$ in F1Santa Inês $\mathrm{x}$ NDB fed diet containing CNM. Silva (2010), in measurements of intake and digestibility using the same animals crossbreed and treatments of this research, emphasized that the lower intake observed for F1Santa Inês x NDB was possibly due to consequence of the intake physiological effect regulation.

The CNM inclusion did not affect the intake for F1Dorper $\mathrm{x}$ NDB, although differences for other crossbreeds were observed and lower intake was noticed when CNM was included in the diets.

Barros et al. (2003) commented that amounts of concentrate higher than $35.3 \%$ decreased DM and OM intakes in diets based of Leucaena hay (Leucaena leucocephala), corn, soybean meal and mineral salts, in balanced rations, supplied to F1Somalis $\mathrm{x}$ NDB and to F1Santa Inês $x$ NDB. The dietary formulations prepared for this study had from $59.35 \%$ (without CNM) to $59.57 \%$ (with CNM) of the concentrate, which may have limited the OM intake, especially in F1Santa Inês x NDB.

Significant interaction $(\mathrm{P}<0.05)$ between crossbreeds and the experimental diets was not observed for average day gain (ADG) and feed:gain ratio (FGR) (Table 4). The F1Dorper $x$ NDB had an ADG of $0.262 \mathrm{~kg}$ per day, which was greater than ADG for F1Somalis $\mathrm{x}$ NDB and for F1Santa Inês x NDB, whose ADG were 0.201 and $0.181 \mathrm{~kg}$ per day, respectively.

The lowest ADG $(0.184 \mathrm{~kg}$ per day) occurred in animals fed diet contained CNM, although no significant difference was found for FGR concerning the CNM inclusion or not in the diets and the crossbreeds (Table 4).

Amaral et al. (2011b) evaluated the economic performance of three genetic groups of feedlot lambs: Santa Inês, F1Dorper x Santa Inês, and F1White Dorper $\mathrm{x}$ Santa Inês. These authors noticed that F1Dorper $x$ Santa Inês and F1White Dorper x Santa Inês lambs presented higher ADG than Santa Inês lambs, similar to results observed in this study. These authors also observed a feed:gain ratio values of 3.52 and $3.65 \mathrm{~kg}$ for DM intake per $\mathrm{kg}$ of weight gain to F1Dorper x Santa Inês and F1White Dorper x Santa Inês, respectively. The value obtained for F1Dorper $x$ Somalis in this study were higher compared to results observed for those authors. Pereira et al. (2010) reported that animals from breeds with higher weight gain during the growing period usually require less DM of feed per $\mathrm{kg}$ of weight gain. 
Table 4. Average daily gain (ADG), Feed:Gain Ratio (FGR) of sheep from different crossbreeds being fed diets with or without cashew nut meal CNM

\begin{tabular}{lcc}
\hline Variables & ADG & FGR \\
\hline Genetic Groups & kg per day & kg of DM Intake per kg of gain \\
\hline F1Dorper x NDB & $0.262^{\mathrm{A}}$ & 3.87 \\
F1Somalis x NDB & $0.201^{\mathrm{B}}$ & 3.87 \\
F1Santa Inês x NDB & $0.181^{\mathrm{B}}$ & 4.20 \\
\hline Diets & $\mathrm{kg}$ per day & $\mathrm{kg}$ of DM intake per kg of gain \\
\hline Without CNM & $0.184^{\mathrm{B}}$ & 4.28 \\
With CNM & $0.246^{\mathrm{A}}$ & 4.05 \\
\hline Coefficient of Variation $(\%)$ & 16.1 & 14.1 \\
\hline
\end{tabular}

*Averages with the same letters in the same column do not differ significantly through the SNK test $(\mathrm{P}>0.05)$.

The body weight at slaughter was affected by diet, and a significant interaction $(\mathrm{P}<0.05)$ between diet and crossbreeds (Table 5) was observed. The diet with inclusion of CNM had lowest average body weight at slaughter for F1Santa Inês $x$ NDB than other crossbreeds. With regard to the diet without inclusion of CNM for this variable, no differences were observed.
Lower weights for F1Dorper x NDB and F1Santa Inês x NDB were observed, with 28.5 and $20.7 \mathrm{~kg}$, respectively, thus showing that these crossbreeds can reduce ADG with diets containing high levels of EE. This variable was not affected by inclusion of $\mathrm{CNM}$ in the diets for F1Somalis x NDB.

Table 5. Slaughter weight (SW) in kg of sheep from different crossbreeds fed diets with or without cashew nut meal (CNM)

\begin{tabular}{lcccc}
\hline \multirow{2}{*}{ Variable } & \multirow{2}{*}{ Diets } & F1Dorper x & F1Somalis x & F1Santa Inês x \\
\cline { 3 - 5 } & & NDB & NDB & NDB \\
\hline \multirow{2}{*}{ BodyWeight } & Without CNM & $31.9^{\mathrm{Aa}}$ & $28.7^{\mathrm{Aa}}$ & $28.8^{\mathrm{Aa}}$ \\
& With CNM & $28.5^{\mathrm{Ba}}$ & $27.8^{\mathrm{Aa}}$ & $20.7^{\mathrm{Bb}}$ \\
\hline & Days of feedlot & 21 & 35 & 54 \\
\hline
\end{tabular}

Coefficient of Variation $=5.40 \%$.

*Averages with the same lowercase letters in the same row do not differ significantly through the SNKtest $(\mathrm{P}>0.05)$; **Averages with the same uppercase letters in the same column do not differ significantlythrough the SNK test $(\mathrm{P}>0.05)$. 
Diets with inclusion of CNM provided lower slaughter weights, except for F1Santa Inês x NDB, that had a slaughter weight of $20.7 \mathrm{~kg}$ (Table 5). Although the values of feed:gain ratio were similar between treatments (Table 4). F1Dorper $x$ NDB reached the slaughter weight (28 to $30 \mathrm{~kg} / \mathrm{BW}$ ) faster than the other crossbreeds (Table 5) and this can reduce costs in feedlot.

According to Mertens (1994), variations in $\mathrm{ADG}$ are related to $\mathrm{DM}$ intake by animals and, among the factors involved in the intake regulation are included energy intake by the animal and the concentration of NDF in the diet which is considered a limiting factor due to its slow degradation and low passage rate in the rumen. Van Soest (1994) considered that intake is directly associated with the nutrient supply and with meeting the nutritional requirements of animals, which is the main determinant of animal performance.

The lower body weight at slaughter of F1Santa Inês x NDB (Table 5) probably occurred as a result of lower ADG and lower DM intakes (DMI). The correlations between body weight at slaughter and ADG and between body weight at slaughter and DMI were high, $\mathrm{r}=0.7875 \quad(\mathrm{P}<0.0001)$ and $\mathrm{r}=0.8388$ $(\mathrm{P}<0.00001)$, respectively.

The energy is the main nutrient that affects negatively the performance of ruminants in production systems based on forage resources and agribusiness residues and according to Barroso et al. (2006), many authors related that energy is the nutrient that shows most difficult to be reached in ideal levels in the diets. Such problem was not observed in the diets of this study, because the values of dietary TDN ranged from $68.36 \%$ to $68.46 \%$ in diets with and without CNM, respectively (Table 2 ), higher than value prescribed by NRC (2007), though satisfactory for the different crossbreeds assessed.

The inclusion CNM in the diets and crossbreeds had no influence $(\mathrm{P}>0.05)$ on the carcass weight and on the yield of leg, loin, shoulder and neck (Table 6).

When the CNM was added in the experimental diets, an inferior cold carcass weight $(\mathrm{CCW})$ was observed for animals fed with that diet $(11.9 \mathrm{~kg})$. F1Santa Inês x NDB was the crossbreed that showed the lowest CCW $(11.3 \mathrm{~kg})$.

For the rib weight lower average values $(3.75 \mathrm{~kg})$ were observed for diet with CNM compared to the control diet $(4.42 \mathrm{~kg})$. Regarding cold carcass yield (CCY), that is a percentage of $\mathrm{CCW}$ in relation of total body weight, a higher value for the crossbreeds F1Somalis $\mathrm{x}$ NDB and F1 Dorper $x$ NDB (13.5 and $13.4 \mathrm{~kg}$, respectively) was noticed, when compared to F1Santa Inês $\mathrm{x}$ NDB (11.3kg).

The amount of DM intake is an important measure for making nutritional inferences in the response of animal performance. The Pearson correlation, obtained for the weights of commercial cuts and DM intake, was higher than $50 \%$, on average $(\mathrm{P}<0.01)$. On the rib weight was observed an effect of DM intake more evident $(\mathrm{r}=0.5708 ; \mathrm{P}<0.0001)$. As a result, the F1Santa Inês x NDB had lower weight of this cut on the test diet (Table 6).

The CCY is the weight most practiced by refrigerators and more important for chain productive of the meat sheep (FURUSHO-GARCIA et al., 2004; ARAÚJO FILHO et al., 2010), besides being the most recommended way to maintain the total quality of animal meat. The CCY can be influenced by several factors such as breed, crossing and 
production systems, and this influence may be greater in confined F1 animals by crossing with breeds specialized for meat. The reduction in CCY of the F1Santa Inês x NDB lambs may be directly related to the slaughter weight of animals $(20.73 \mathrm{~kg})$, which was lower in those fed diets containing $\mathrm{CNM}$, as a result of lower feed intake observed for this crossbreed with this diet type.

Table 6. Weight $(\mathrm{kg})$ and percentage (\%) of cold carcass yield (CCY) and commercial cuts of sheep from different crossbreeds being fed with diets containing or not cashew nut meal $(\mathrm{CNM})$

\begin{tabular}{|c|c|c|c|c|c|c|c|}
\hline \multirow[b]{2}{*}{ Variables } & \multirow[b]{2}{*}{ Units } & \multicolumn{3}{|c|}{ Crossbreeds } & \multicolumn{2}{|c|}{ Diets } & \multirow{2}{*}{$\begin{array}{l}\mathrm{CV} \\
(\%)\end{array}$} \\
\hline & & $\begin{array}{c}\text { F1Dorper } \\
\text { x NDB }\end{array}$ & $\begin{array}{c}\text { F1Somalis } \\
\text { x NDB }\end{array}$ & $\begin{array}{c}\text { F1Santa Inês } \\
\text { x NDB }\end{array}$ & $\begin{array}{l}\text { With } \\
\text { CNM }\end{array}$ & $\begin{array}{l}\text { Without } \\
\text { CNM }\end{array}$ & \\
\hline \multirow{2}{*}{$\mathrm{CCW}$} & $\mathrm{kg}$ & $13.4^{\mathrm{a}}$ & $13.5^{\mathrm{a}}$ & $11.3^{\mathrm{b}}$ & $11.9^{\mathrm{b}}$ & $13.6^{\mathrm{a}}$ & $7.05^{\mathrm{c}}$ \\
\hline & $\%$ & $44.3^{\mathrm{b}}$ & $47.98^{\mathrm{a}}$ & $45.7^{\mathrm{b}}$ & 46.3 & 45.7 & 2.80 \\
\hline \multirow{2}{*}{ Leg } & $\mathrm{kg}$ & 4.10 & 4.19 & 3.64 & 3.83 & 4.12 & 12.4 \\
\hline & $\%$ & 30.6 & 31.0 & 32.4 & 32.4 & 30.3 & 11.8 \\
\hline \multirow{2}{*}{ Loin } & $\mathrm{kg}$ & 1.64 & 1.64 & 1.36 & 1.44 & 1.65 & 21.4 \\
\hline & $\%$ & 12.2 & 12.1 & 12.0 & 12.1 & 12.1 & 18.5 \\
\hline \multirow{2}{*}{ Rib } & $\mathrm{kg}$ & $4.28^{\mathrm{a}}$ & $4.47^{\mathrm{a}}$ & $3.50^{\mathrm{b}}$ & $3.75^{\mathrm{b}}$ & $4.42^{\mathrm{a}}$ & 11.5 \\
\hline & $\%$ & 31.8 & 33.0 & 30.8 & 31.4 & 32.4 & 7.42 \\
\hline \multirow{2}{*}{ Shoulder } & $\mathrm{kg}$ & 2.28 & 2.32 & 2.04 & 2.09 & 2.34 & 13.5 \\
\hline & $\%$ & 16.9 & 17.2 & 18.0 & 17.6 & 17.2 & 8.44 \\
\hline \multirow{2}{*}{ Neck } & $\mathrm{kg}$ & 1.09 & 0.890 & 0.880 & 0.910 & 1.00 & 15.6 \\
\hline & $\%$ & 8.10 & 6.58 & 7.82 & 7.66 & 7.33 & 15.7 \\
\hline
\end{tabular}

*Averages with the same lowercase letters in the same row do not differ significantly through the SNK test $(\mathrm{P}>0.05) ; * *$ Averages with the same uppercase letters in the same column do not differ significantly through the SNK test (P>0.05); CCW: Cold Carcass Weight; CV: Coefficient of Variation.

Among the cuts, the leg is considered the noblest part of lamb carcass and it represents the greatest accumulation of muscle mass. Thus, its tissue composition is of great importance for assessing the quality of carcass. The inclusion of CNM in the diets for lambs reduces feed intake and carcass yield. Among the crossbreeds, the F1Dorper $x$ NDB sheep have higher average daily gain rate.

\section{REFERENCES}

AMARAL, R.M.; MACEDO, F.A.F.; MACEDO, F.G.; LINO, D.A.; ALCALDE, C.R.; DIAS,F.B.; GUALDA, T.P. Deposição tecidual em cordeiros Santa Inês, $1 / 2$ Dorper-Santa Inês e $1 / 2$ White Dorper-Santa Inês avaliados por ultrassonografia. Revista Brasileira de Saúde e Produção Animal [Online], v.12, n.3, p.658-669, 2011a. 
AMARAL, R.M.; MACEDO, F.A.F.; ALCALDE, C.R.; LINO, D.A.; BÁNKUTI, F.I.; MACEDO, F.G.; DIAS, F.B.; GUALDA, T.P. Desempenho produtivo e econômico de cordeiros confinados abatidos com três espessuras de gordura. Revista Brasileira de Saúde e Produção Animal [Online], v.12, n.1, p.155-165, $2011 b$.

ARAÚJO FILHO, J.T.; COSTA, R.G.; FRAGA, A.B.; SOUSA, W.H.; CEZAR, M.F.; BATISTA, A.S.M. Desempenho e composição da carcaça de cordeiros deslanados terminados em confinamento com diferentes dietas. Revista Brasileira de Zootecnia, v.39, n.2, p.363-371, 2010.

ASSOCIATION OF OFFICIAL ANALYTICAL CHEMISTS - AOAC. Official Methods of Analysis. 18th ed. Gaithersburg, MD, 2006.

BARROS, N.N.; VASCONCELOS, V.R.; ARAÚJO, M.R.A.; MARTINS, E.C. Influência do grupo genético e da alimentação sobre o desempenho de cordeiros em confinamento. Pesquisa Agropecuária Brasileira, v.38, n.9, p.1111-1116, 2003.

BARROSO, D.D.; ARAÚJO, G.G.L.; SILVA, D.S.; GONZAGA NETO, S.; MEDINA, F.T. Desempenho de ovinos terminados em confinamento com resíduo desidratado de vitivinícolas associado a diferentes fontes energéticas. Ciência Rural, v.36, n.5, p.1553-1557, 2006.

CAPPELLE, E.R.; VALADARES FILHO, S.C.; SILVA, J.F.C.; CECON, P.R.

Estimativas do valor energético a partir de características químicas e bromatológicas dos alimentos. Revista Brasileira de Zootecnia, v.30, n.6, p.1837-1856, 2001.
CARTAXO, F.Q.; SOUSA, W.H.; COSTA, R.G., CEZAR, M.F.; PEREIRA FILHO, J.M.; CUNHA, M.G.G.C. Características quantitativas da carcaça de cordeiros de diferentesgenótipos submetidos a duas dietas. Revista Brasileira de Zootecnia, v.40, n.10, p.2220-2227, 2011.

DEVENDRA, C., LEWIS, D. The interaction between dietary lipids and fiber in the sheep. 2. Digestibity studies. Animal Production, v.19, n.1, p.67-76, 1974.

FURUSHO-GARCIA, I.F.; PEREZ, J.R.O.; BONAGURIO, S.; LIMA, A.L.; QUINTÃO, F.A. Estudo dos cortes da carcaça de cordeiros Santa Inês puros e cruzas Santa Inês com Texel, Ile de France e Bergamácia. Revista Brasileira de Zootecnia, v.33, n.2, p.453-462, 2004.

INSTITUTO BRASILEIRO DE GEOGRAFIA E ESTATÍSTICA - IBGE. [2011]. Estatísticas sobre o rebanho, e a produção de rebanho. Disponível em: $<$ http://www.sidra.ibge.gov.br>. Acesso em 12/06/2011.

MAHGOUB, O.; KHANB, A.J.; ALMAQBALYA, R.S.; AL-SABAHI J.N.; ANNAMALAI, K.; AL-SAKRY, N.M. Fatty acid composition of muscle and fat tissues of Omani Jebel Akhdar goats of different sexes and weights. Meat Science, v.61, n.4, p.381-387, 2002.

MENEZES, L.F.G.; RESTLE, J.; BRONDANI, I.L. Características da carcaça de novilhos de gerações avançadas do cruzamento alternado entre as raças charolês e nelore, terminados em confinamento. Revista Brasileira de Zootecnia, v.34, n.3, p.934-945, 2005. 
MERTENS, D.R. Creating a system for meeting the fiber requirements of dairy cows. Journal of Dairy Science, v.80, p.1463-1481, 1997.

MERTENS, D.R. Regulation of forage intake. In: FAHEY JR., G.C. (Ed.) Forage quality, evaluation and utilization. Madison: American Society of Agronomy, 1994. p.450-493.

MORENO, G.M.B.; SILVA SOBRINHO, A.G.; ROSSI, R.C.; PEREZ, H.L.; LEÃO, A.G.; ZEOLA, N.M.B.L.; SOUZA JÚNIOR, S.C. Desempenho e rendimentos de carcaça de cordeiros Ile de France desmamados com diferentes idades. Revista Brasileira de Saúde de Produção Animal [Online], v.11, n.4, p.1105-1116, 2010.

NATIONAL RESEARCH COUNCIL NRC. Nutrient requirements of sheep. 6.ed. Washington, D.C.: NationalAcademy Press, 1985. 99p.

NATIONAL RESEARCH COUNCIL NRC. Nutrient Requirements of Small Ruminants: Sheep, Goats, Cervids, and New World Camelids. 1.ed. Washington, D.C.: NationalAcademy Press, 2007. 384p.

PALMQUIST, D.L.; JENKINS, T.C. Fat in lactation rations: review. Journal of Dairy Science, v.63, p.1-14, 1980.

PEREIRA, E.S.; PIMENTEL, P.G.; FONTENELE, R.M.; MEDEIROS, A.N.; REGADAS FILHO, J.G.L.; SELAIVE VILLARROEL, A.B. Características e rendimentos de carcaça e de cortes em ovinos Santa Inês, alimentados com diferentes concentrações de energiametabolizável. Acta Scientiarum. Animal Sciences, v.32, n.4, p.431-437, 2010.
PIMENTEL, P.G.; MOURA, A.A.A.N.; NEIVA, J.N.M., ARAÚJO, A.A., TAIR, R.F.L. Consumo, produção de leite e estresse térmico em vacas da raça PardoSuíça alimentadas com castanha de caju. Arquivo Brasileiro de Medicina Veterinária e Zootecnia, v.59, n.6, p.1523-1530, 2007.

SAMPAIO, I.B.M. Estatística aplicada à experimentação animal. 3.ed. Belo Horizonte: Fundação de Ensino e Pesquisa em Medicina Veterinária e Zootecnia, 2007. 264p.

SIMPLÍCIO, A.A.; SIMPLÍCIO, K.M.M.G. Goat and sheep production cut: challenges and opportunities. CFMV Journal, v.12, n.39, p.7-18, 2006.

SILVA, V.L. Valor nutritivo de dietas contendo farelo de castanha de caju para cordeiros mestiços. 2010. 124f. Dissertação (Mestrado em Zootecnia) Universidade Estadual Vale do Acaraú, Sobral.

SILVA, V.L.; ROGÉRIO, M.C.P.; ALVES, A.A.; BOMFIM, M.A.D.; LANDIM, A.V.; LEITE, E.R.; COSTA, H.H.A.; FREIRE, A.P.A. Ingestive behavior of sheep fed diets containing cashew nut meal. Journal of the Faculty of Animal Science, Veterinary and Agronomy (PUCRS. Uruguaiana), v.18, n.1, p. 1-17, 2011.

SNIFFEN, C.J.; O'CONNOR, J.D.; VAN SOEST, P.J.; FOX, D.G.; RUSSELL, J.B. A net carbohydrate and protein system for evaluating cattle diets: II. Carbohydrate and protein availability. Journal of Animal Science, v.70, n.11, p.35623577, 1992. 
UNIVERSIDADE FEDERAL DE

VIÇOSA - UFV. SAEG - Sistemas de Análises Estatísticas e Genéticas.

Versão 8.0. Viçosa, MG, 2000.

VAN SOEST, P.J. Nutritional Ecology

of the Ruminant. 2.ed. Ithaca: Comstock

Publication Association, 1994. 476p.
VAN SOEST, P.J.; ROBERTSON, J.B.; LEWIS, B.A. Methods for dietary fiber, neutral detergent fiber, and nonstarch polysaccharides in relation to animal nutrition. JournalofDairy Science, v.74, n.10, p.3583-3597, 1991.

Data de recebimento: 17/09/2011

Data de aprovação: 18/11/2012 